\title{
Effect of Starch on Mechanical, Electrical, Physical, Thermal Properties and Photo/Bio-Degradation of Hips - Starch Blend
}

\author{
Subburaj. J and Soundararajan. S* \\ *Dept of Plastics Technology/Central Institute of Plastics Engineering and Technology (CIPET), Chennai-600 \\ 032, India.
}

\begin{abstract}
HIPS was blended with starch in three formulations 10, 20 \& 30\% with compatibilizer glycerol (2wt\% based on starch) using a twin screw extruder. Test specimens were prepared using an injection molding machine. Mechanical, electrical, physical and thermal properties were determined. Photo degradation using accelerated weather o meter for 25, 50, 100, $200 \mathrm{hrs}$ was carried out. And then bio degradation for 45 days was carried out. The loss in mechanical properties was studied after photo degradation. After photo degradation, bio degradation was evaluated. The effect of starch on bio degradation was studied. HIPS is photo degradable and starch is bio degradable. Hence starch filled HIPS is photo \& bio degradable. This photo \& bio degradable starch filled HIPS is used in packaging \& disposable applications like cups, lids, trays, spoons, pens \& cutlery handles with lower cost.
\end{abstract}

Keywords: HIPS, starch, Mechanical properties, photo degradation, bio degradation

\section{Introduction}

The disposal of plastic solid waste is primarily accomplished by land filling, degradation, and recycling. Degradation is highly justified in some applications [1].

The various types of polymeric degradations along with their mechanisms, which include photooxidative degradation, thermal degradation, ozone-induced degradation, mechano chemical degradation, catalytic degradation and bio degradation[2]. There are different methods available to study these degradations and the factors that affect these degradations.

With the increased production of municipal solid waste by the disposal of plastic materials, there is a need to develop new biodegradable materials and biodegrade existing plastic materials in daily use. High impact Polystyrene and expanded polystyrene are commodity plastics that are extensively used in packaging and other applications. Six bacterial isolates were isolated from soil buried expanded polystyrene films showing adherence and growth with the polystyrene as a sole carbon source. Scanning electron microscopy (SEM) of the film surface used for isolation showed extensive microbial growth [3]. The preliminary screening of biodegradation capability was done by Fourier transform infrared (FTIR) spectroscopy for surface chemical changes and high pressure liquid chromatography (HPLC) for analysis of biodegradation products. Bacterial isolates NA26, NB6, NB26 showed the production of biodegradation products in the extracellular media indicating biodegradation process.

Blending of polymers has been extensively utilized to obtain improved mechanical properties. A wide range of immiscible polymers have been blended using melt mixing processes like an internal mixer or an extruder to analyze the resultant morphologies and their characteristics.

Twin screw extrusion is used extensively for mixing, compounding, or reacting polymeric materials. The flexibility of twin screw extrusion equipment allows this operation to be designed specifically for the formulation being processed. For example, the two screws may be co rotating or counter rotating, intermeshing or non intermeshing. In addition, the configurations of the screws themselves may be varied using forward conveying elements, reverse conveying elements, kneading blocks, and other designs in order to achieve particular mixing.

Photo degradation is degradation of a photodegradable molecule caused by the absorption of photons, particularly those wavelengths found in sunlight, such as infrared radiation, visible light, and ultraviolet light. However, other forms of electromagnetic radiation can cause photo degradation. Photo degradation includes photo dissociation, the breakup of molecules into smaller pieces by photons. It also includes the change of a molecule's shape to make it irreversibly altered, such as the denaturing of proteins, and the addition of other atoms or molecules. A common photo degradation reaction is oxidation. This type of photo degradation is used by some drinking water and wastewater facilities to destroy pollutants.

Biodegradation is the chemical breakdown of materials by a physiological environment. The term is often used in relation to ecology, waste management and environmental remediation (bioremediation). Organic www.iosrjournals.org 
material can be degraded aerobically with oxygen, or anaerobically, without oxygen. A term related to biodegradation is bio mineralisation, in which organic matter is converted into minerals. Bio surfactant, an extracellular surfactant secreted by micro organisms, enhances the biodegradation process [4, 5 \& 6].

HIPS is photo degradable and starch is bio degradable. Starch is one of the renewable resources and abundantly available in the form of plant produce such as maize, corn, tapioca, sago, potato. Hence starch filled HIPS is photo \& bio degradable. This photo \& bio degradable starch filled HIPS is used in packaging \& disposable applications like cups, lids, trays, spoons, pens \& cutlery handles with lower cost which can be manufactured either by thermoforming or inj molding techniques.

In this present study, the starch is blended with HIPS and their mechanical, thermal, electrical and physical properties were evaluated. Photo degradation and bio-degradation were also carried out. The effect of starch on Tensile strength and hardness properties before and after UV-accelerated weathering were also reported.

\subsection{Materials}

\section{Experimental}

HIPS was purchased from LG polymers India pvt ltd, Chennai . Starch was purchased from local suppliers. Glycerol was purchased from Merck chemicals, Chennai.

\subsection{Twin Screw Compounding}

HIPS was blended with starch in three formulations $10,20 \& 30 \%$ with compatibilizer glycerol ( $2 \%$ based on starch) using a twin screw extruder. Glycerol is added minimum amount to avoid cross linking and compatibility of HIPS and starch. The temp range of twin screw extruder is $90{ }^{\circ} \mathrm{C}$ to $210 \mathrm{deg}{ }^{\circ} \mathrm{C}$

\subsection{Specimen Preparation}

Using that granules tensile, flexural, impact, hardness, HDT,VSP, surface resistivity, volume resistivity, arc resistance, water absorption test specimens were prepared by an Windsor injection molding machine (SP 130) as per ASTM standards.

The temp range of injection molding machine is $180^{\circ} \mathrm{C}$ to $230^{\circ} \mathrm{C}$

\subsection{TESTING}

Tensile test was carried out in Universal Testing Machine (Shimadzu AUTOGRAPH tensile tester). Tensile samples of dimension $165 \times 13 \times 3 \mathrm{~mm}$ (Type I dumbbells) were tested at a gauge length of $50 \mathrm{~mm}$ and crosshead speed of $50 \mathrm{~mm} / \mathrm{min}$ as per ASTM D638.Flexural test was carried out in Universal Testing Machine (UTM, Instron 3382, UK). Flexural samples of dimension $127 \mathrm{~mm} \times 12.7 \mathrm{~mm} \times 3.2 \mathrm{~mm}$ were tested at a crosshead speed of $10 \mathrm{~mm} / \mathrm{min}$ as per ASTM 790. Izod Impact test a notch angle of $45^{\circ}$ with a V notch depth of $2.54 \mathrm{~mm}$ was made with a notch cutter (M/s CEAST, Italy) on specimens having dimension of $63.5 \times 12.7 \times 3$ $\mathrm{mm}$. Subsequently the measurements were carried out in an Izod Impact Tester (M/s CEAST, Italy) as per ASTM D256. Hardness was done by shore D hardness tester. The test specimen size is $63.5 \times 12.7 \times 3 \mathrm{~mm}$.

Surface resistivity was done in tero ohm meter as per ASTM D257. The test specimen size is $110 \mathrm{~mm}$ dia $\times 3.2 \mathrm{~mm}$ thickness. Volume resistivity was done in tero ohm meter as per ASTM D257. The test specimen size is $110 \mathrm{~mm}$ dia $\times 3.2 \mathrm{~mm}$ thickness. Arc resistance was done in high voltage low current equipment (ceast, italy) as per ASTM D495. The test specimen size is $110 \mathrm{~mm}$ dia $\times 3.2 \mathrm{~mm}$ thickness.

Water absorption: Three specimens of dimension $50 \mathrm{~mm}$ dia $\times 3 \mathrm{~mm}$ thick were tested for water absorption and the results were presented as average of three at a temperature of $23^{\circ} \mathrm{C}$ for $24 \mathrm{hrs}$. density was done as per ASTM D 792. Shrinkage was done as per ASTMD 955. The Melt Flow Index (MFI) test was done by using granules at $230^{\circ} \mathrm{C} \& 2.16 \mathrm{~kg}$ load in Lloyd equipment (UK). The Vicat softening point (VSP) was done using HDT/VSP equipment, Wallace (UK). The dimensions of test specimen is $12.7 \times 12.7 \times 3.2 \mathrm{~mm}$.

\subsection{Photo Degradation \& Bio Degradation}

The tensile specimens of 12 numbers kept in Xenon Accelerated weather- o- meter. After 25, 50, 100, 200 hours, 3 specimens were taken from virgin HIPS, HIPS with 10\% starch, HIPS with $20 \%$ starch, HIPS with $30 \%$ starch from the weather -o- meter respectively. The test specimens were exposed as per ASTM G154 standard. The phase I dry arc for $102 \mathrm{~min}$; phase II water (rain) spray for $18 \mathrm{~min}$. Chamber temp is $23 \mathrm{C}$ and black panel temp $45 \mathrm{C}$ and the irradiation dose at $310 \mathrm{~nm}$ is $0.53 \mathrm{~W} / \mathrm{mm}$

Biodegradation is done by soil burial method for 45 days. The weight of the samples are measured before and after biodegradation. And then the weight loss is calculated. From that we can know the degradation rate. 


\subsection{PROCESSABILITY}

The effect of starch on sheet formation of HIPS of thermoforming grade. HIPS was blended with starch in three formulations $10,20 \& 30 \%$ with compatibilizer glycerol (2\% based on starch) using a twin screw extruder (Haake's Rheo gram) with a rpm 100. Glycerol is added minimum amount to avoid cross linking and only compatibility of HIPS and starch takes place. The temp range of twin screw extruder is 90 to $210^{\circ} \mathrm{C}$.

\section{RESULTS AND DISCUSSIONS}

The result were shown in Tables 1-4 and also in Figures 1-9

\subsection{Mechanical properties}

It is evident from the test result that with increase in starch content from $10 \%$ to $30 \%$, there is a decrease in tensile strength and modulus as compared with virgin HIPS. The decrease in tensile strength and tensile modulus of virgin HIPS with the addition of starch is due to the presence of soft elastomeric phase that reduces the crystallinity and stress level of virgin HIPS.

Tensile strength (Fig 1) \& Tensile modulus (Table 1) were measured before and after photo degradation. Before weathering the tensile strength $\&$ modulus decreases when addition of starch due to rigidity of starch. The tensile strength \& modulus decreases after weathering because of photo degradation of HIPS due to unsaturation in Poly butadiene units. After photo degradation the molecular chain length (Mol.wt) lower and so the specimen becomes brittle. The elongation at break $(\mathrm{Eb})$ will be lower than $5 \%$. Before UV exposure the Eb were higher than $5 \%$.

The incorporation of starch on HIPS reduces the flexural strength and flexural modulus ( Fig 2). This is due to the against reinforcing effect of starch on HIPS. Because of rubber phase of HIPS the specimen tends to bend. Impact strength (Fig 3) decreases because starch acts as a filler and hence the rigidity increases and flexibility decreases, and hence impact decreases .

Hardness (Fig 4) increases on addition of starch due to the rigidity of starch.

\subsection{ELECTRICAL PROPERTIES}

Starch is polar and hydrophelic in nature, so it absorbs moisture. Hence the electrical properties like Surface Resistivity (Table 2), Volume resisitivity (Fig 5) and Arc resisitance (Table 2) are decreasing on addition of starch. The specimen is having good insulation characteristics because of polystyrene, eventhough HIPS may have some unsaturation in the butadiene units which may lead to electronic conductivity.

\subsection{PHYSICAL PROPERTIES}

Water absorption (Table 3) increases on addition of starch, because starch is hydrophilic as mentioned above and hence absorbs more water than that of HIPS.

The value of shrinkage decreases on addition of starch due to filling effect of starch.

Density decreases on addition of starch because of lighter weight of starch.

\subsection{THERMAL PROPERTIES}

Melt Flow Index (MFI) (Table 4) decreases because of raw starch is having high molecular weight about one million and has very high melt viscosity in the HIPS-starch blend. The high melt viscosity of starch restricts the flow and lowers the MFI when compared to HIPS.

Vicat softening point (VSP) increases on adding of starch, because of high molecular weight of starch and it is having hard, rigid and brittle characteristics. Due to increase in VSP, the service temp will be increased

\subsection{PHOTO DEGRADATION}

HIPS is photo degradable because the unsaturated double bond of poly butadiene breaks due to UV light and thermal oxidative degradation takes place. So the long chain polymer molecules become low molecular weight. After photo degradation the specimen gets degraded and becomes brittle when the elongation is less than 5\%. After prolonged UV light exposure in the accelerated weather-o-meter or after about 5-6 months in the out-door sunlight, the HIPS will be having lower mol. weights about 1000-3000.

\subsection{BIO DEGRADATION}

After 200 hours of photo degradation in the, bio degradation was evaluated. Starch was easily biodegradable. But the HIPS which is photo-degradable, is not much bio-degradble. Only after longer UV or out-door exposure and becoming low molecular weights, the HIPS part polymer chain can be easily attacked by micro organisms and become bio-degradable. i.e HIPS is photo-degradable and starch is bio-degradable. 
Hence, starch filled HIPS is photo \& bio-degradable. So there will be little or no residue left in the environment after 5 to 6 months.

\subsection{SCANNING ELECTRON MICROSCOPE (SEM)}

From the SEM images, we can know HIPS(6a) and starch found to be compatible before weathering (Fig. 7a, 8a \& 9a). After 200 hours of UV accelerated weathering of HIPS and starch blends, the HIPS was degraded (Fig. 6 b, $7 b, 8 b$ \& $9 \mathrm{~b}$ ) because of UV light due to photo degradation. And due to the water spray, the starch was hydrolysed. The Starch is partly soluble in water and so it may be dissolved and/or eroded easily

\subsection{PROCESSABILITY}

The processability becomes difficult when addition of starch content increases from $10 \%$ to $30 \%$, because starch is having high melt viscosity and high molecular weight. So it resists the flow. Compounding can be done easily upto $30 \%$ without any difficulty. Upto $10 \%$ starch, the films were easily forming. and are semi rigid.

\section{CONCLUSION}

It is found that tensile strength \& modulus, flexural strength \& modulus, impact strength, surface resistivity, volume resistivity, arc resistance, shrinkage, density, MFI values were decreasing. Hardness, water absorption, VSP values were increasing. HIPS is photo degradable and starch is bio degradable. Hence starch filled HIPS is photo \& bio degradable. This photo \& bio degradable starch filled HIPS will be useful in food packaging \& disposable applications like cups, lids, trays, spoons, pens \& cutlery handles with lower cost and eco friendly. There will be only little residue left in the environment after 5 to 6 months.

\section{References}

[1] C. F. Jasso G' L. J. González-Ortiz, R. Contreras J., E. Mendizábal M., J. Mora G,.The degradation of high impact polystyrene with and without starch in concentrated activated sludge, Polymer Engineering \& ScienceVolume 38, Issue 5, pages 863-869, May 1998

[2] Baljit Singh and Nisha Sharma Mechanistic implications of plastic degradation, Polymer Degradation and Stability Volume 58, Issue 4, December 2009, Pages 116-126

[3] Naima Atiq, Safia Ahmed, M. Ishtiaq Ali, Saadia Andleeb, Bashir Ahmad and Geoffery Robson,Isolation and identification of polystyrene biodegrading bacteria from soil, African Journal of Microbiology Research, Vol. 4(14), pp. 1537-1541, 18 July, 2010

[4] FranciscoVilaplana, AmparoRibes-Greus and SigbrittKarlsson, Chromatographic pattern in recycled high-impact polystyrene (HIPS) Occurrence of low molecular weight compounds during the life cycle, Polymer Degradation and Stability Volume 95, Issue 2, February 2010, Pages 172-186

[5] Woo Yeul Jang, Boo Young Shin, Tae Jin Lee, and Ramani Narayan, Thermal Properties and Morphology of Biodegradable PLA/Starch Compatibilized Blends, J. Ind. Eng. Chem., Vol. 13, No. 3, (2007) 457-464

[6] Lakshmi S. Nair and Cato T. Laurencin, Biodegradable polymers as biomaterials Progress in Polymer Science, Volume 32, Issues 89, August September2007,Pages762-798, 91 (2006) 1226-1232

\section{CAPTIONS TO FIGURES}

Fig 1. Tensile Strength before and after UV weathering of HIPS-Starch blends

Fig 2 . Flexural Strength and Modulus of HIPS-Starch blends

Fig. 3 IMPACT STRENGTH of HIPS-Starch blends

Fig.4 HARDNESS of HIPS-Starch blends

Fig.5 VOLUME RESISTIVITY of HIPS-Starch blends

Fig. 6(a) Virgin HIPS before weathering

Fig. 6 (b) Virgin HIPS after weathering

Fig. 7 (a) HIPS with 10\% starch before weathering

Fig. 7 (b) HIPS with $10 \%$ starch after weathering

Fig. 8(a) HIPS with 20\% starch before weathering

Fig. 8(b) HIPS with $20 \%$ starch after weathering

Fig. 9(a) HIPS with $30 \%$ starch before weathering

Fig. 9 (b) HIPS with 30\% starch after weathering 
TABLE 1 MECHANICAL PROPERTIES OF HIPS \& STARCH BLEND

\begin{tabular}{|c|c|c|c|c|c|c|}
\hline PROPERTIES & METHOD & UNIT & $\begin{array}{l}\text { VIRGIN } \\
\text { HIPS }\end{array}$ & $\begin{array}{l}10 \% \\
\text { STARCH }\end{array}$ & $\begin{array}{l}20 \% \\
\text { STARCH }\end{array}$ & $\begin{array}{lr}30 & \% \\
\text { STARCH }\end{array}$ \\
\hline $\begin{array}{lll}\text { Tensile } & & \\
\text { strength at } & 0 \\
\text { hr } & & \end{array}$ & $\begin{array}{l}\text { ASTM D } \\
638\end{array}$ & $\mathrm{~kg} / \mathrm{cm}^{\wedge} 2$ & 340.821 & 355.596 & 349.521 & 351.505 \\
\hline $\begin{array}{l}\text { Tensile } \\
\text { strength after } \\
25 \text { hrs UV } \\
\text { weathering }\end{array}$ & $\begin{array}{l}\text { ASTM D } \\
638\end{array}$ & $\mathrm{~kg} / \mathrm{cm}^{\wedge} 2$ & 326.8 & 328.7 & 299.2 & 300.6 \\
\hline $\begin{array}{l}\text { Tensile } \\
\text { strength after } \\
50 \text { hrs UV } \\
\text { weathering }\end{array}$ & $\begin{array}{l}\text { ASTM D } \\
638\end{array}$ & $\mathrm{~kg} / \mathrm{cm}^{\wedge} 2$ & 289.5 & 270.5 & 250.4 & 233 \\
\hline $\begin{array}{l}\text { Tensile } \\
\text { strength after } \\
100 \text { hrs UV } \\
\text { weathering }\end{array}$ & $\begin{array}{l}\text { ASTM D } \\
638\end{array}$ & $\mathrm{~kg} / \mathrm{cm}^{\wedge} 2$ & 211.1 & 242.7 & 216.2 & 214.2 \\
\hline $\begin{array}{l}\text { Tensile } \\
\text { modulus at } 0 \\
\text { hr }\end{array}$ & $\begin{array}{l}\text { ASTM D } \\
638\end{array}$ & $\mathrm{~kg} / \mathrm{cm}^{\wedge} 2$ & 4945.8 & 7194.3 & 8295.1 & 9983.5 \\
\hline $\begin{array}{l}\text { Tensile } \\
\text { modulus after } \\
25 \text { hrs UV } \\
\text { weathering }\end{array}$ & $\begin{array}{l}\text { ASTM D } \\
638\end{array}$ & $\mathrm{~kg} / \mathrm{cm}^{\wedge} 2$ & 4894.3 & 7092.3 & 8174.6 & 9795.4 \\
\hline $\begin{array}{l}\text { Tensile } \\
\text { modulus after } \\
50 \text { hrs UV } \\
\text { weathering }\end{array}$ & $\begin{array}{l}\text { ASTM D } \\
638\end{array}$ & $\mathrm{~kg} / \mathrm{cm}^{\wedge} 2$ & 4525.5 & 6990.5 & 8047.4 & 9684.1 \\
\hline $\begin{array}{l}\text { Tensile } \\
\text { modulus after } \\
100 \text { hrs UV } \\
\text { weathering }\end{array}$ & $\begin{array}{l}\text { ASTM D } \\
638\end{array}$ & $\mathrm{~kg} / \mathrm{cm}^{\wedge} 2$ & 4230.9 & 6798.7 & 7926.8 & 9476.6 \\
\hline $\begin{array}{l}\text { Tensile } \\
\text { modulus after } \\
200 \text { hrs UV } \\
\text { weathering }\end{array}$ & $\begin{array}{l}\text { ASTM D } \\
638\end{array}$ & $\mathrm{~kg} / \mathrm{cm}^{\wedge} 2$ & 4124.5 & 6694.2 & 7847.1 & 9354.1 \\
\hline $\begin{array}{l}\text { Flexural } \\
\text { strength }\end{array}$ & $\begin{array}{l}\text { ASTM D } \\
790\end{array}$ & & 47.3 & 43 & 36.6 & 34.4 \\
\hline $\begin{array}{l}\text { Flexural } \\
\text { modulus }\end{array}$ & $\begin{array}{l}\text { ASTM D } \\
790\end{array}$ & $\mathrm{MPa}$ & 3215.9 & 3205.7 & 3188.7 & 2984.7 \\
\hline $\begin{array}{l}\text { Izod impact } \\
\text { strength }\end{array}$ & $\begin{array}{l}\text { ASTM D } \\
256\end{array}$ & $\begin{array}{l}\mathrm{Kg} \\
\mathrm{cm} / \mathrm{cm}\end{array}$ & 25.2 & 21.5 & 17.7 & 13.4 \\
\hline $\begin{array}{l}\text { Hardness } \\
\text { before } \\
\text { weathering }\end{array}$ & $\begin{array}{l}\text { ASTM D } \\
2240\end{array}$ & $\begin{array}{l}\text { Shore } \\
\text { D }\end{array}$ & 74 & 77 & 79 & 81 \\
\hline $\begin{array}{l}\text { Hardness } \\
\text { after } \\
\text { weathering }\end{array}$ & $\begin{array}{l}\text { ASTM D } \\
2240\end{array}$ & Shore D & 80 & 82 & 85 & 88 \\
\hline
\end{tabular}


Effect Of Starch On Mechanical, Electrical, Physical, Thermal Properties And Photo/Bio6 Degradation Of Hips - Starch Blend

TABLE 2 ELECTRICAL PROPERTIES OF HIPS \& STARCH BLEND

\begin{tabular}{|l|l|l|l|l|l|l|}
\hline PROPERTIES & METHOD & UNIT & $\begin{array}{l}\text { VIRGIN } \\
\text { HIPS }\end{array}$ & $\begin{array}{l}10 \% \\
\text { STARCH }\end{array}$ & $\begin{array}{l}20 \% \\
\text { STARCH }\end{array}$ & $\begin{array}{l}30 \\
\text { STARCH }\end{array}$ \\
\hline $\begin{array}{l}\text { Surface } \\
\text { Resistivity }\end{array}$ & $\begin{array}{l}\text { ASTM D } \\
257\end{array}$ & ohm & $6.408^{*} 10^{\wedge} 14$ & $5.575^{*} 10^{\wedge} 14$ & $4.684^{*} 10^{\wedge} 14$ & $3.897 * 10^{\wedge} 14$ \\
\hline $\begin{array}{l}\text { Volume } \\
\text { Resistivity }\end{array}$ & $\begin{array}{l}\text { ASTM D } \\
257\end{array}$ & $\begin{array}{l}\text { ohm } \\
\mathrm{cm}\end{array}$ & $7.643^{*} 10^{\wedge} 15$ & $6.564^{*} 10^{\wedge} 15$ & $5.35^{*} 10^{\wedge} 15$ & $4.24^{*} 10^{\wedge} 15$ \\
\hline Arc resistance & $\begin{array}{l}\text { ASTM D } \\
495\end{array}$ & sec & 131 & 127 & 125 & 122 \\
\hline
\end{tabular}

TABLE 3 PHYSICAL PROPERTIES OF HIPS \& STARCH BLEND

\begin{tabular}{|l|l|l|l|l|l|l|}
\hline PROPERTIES & METHOD & UNIT & $\begin{array}{l}\text { VIRGIN } \\
\text { HIPS }\end{array}$ & $\begin{array}{l}10 \% \\
\text { STARCH }\end{array}$ & $\begin{array}{l}20 \% \\
\text { STARCH }\end{array}$ & $\begin{array}{l}30 \\
\text { STARCH }\end{array}$ \\
\hline $\begin{array}{l}\text { Water } \\
\text { absorption }\end{array}$ & $\begin{array}{l}\text { ASTM D D } \\
570\end{array}$ & $\%$ & 0.0342 & 0.2205 & 0.5874 & 1.552 \\
\hline Shrinkage & $\begin{array}{l}\text { ASTM D } \\
955\end{array}$ & $\%$ & 0.1315 & 0.1206 & 0.1174 & 0.1003 \\
\hline Density & $\begin{array}{l}\text { ASTM D D } \\
792\end{array}$ & $\mathrm{~g} / \mathrm{cc}$ & 1.0773 & 1.0675 & 1.0426 & 1.0276 \\
\hline
\end{tabular}

TABLE 4 THERMAL PROPERTIES OF HIPS \& STARCH BLEND

\begin{tabular}{|l|ll|l|l|l|l|l|}
\hline PROPERTIES & METHOD & UNIT & $\begin{array}{l}\text { VIRGIN } \\
\text { HIPS }\end{array}$ & $\begin{array}{l}10 \% \\
\text { STARCH }\end{array}$ & $\begin{array}{l}20 \% \\
\text { STARCH }\end{array}$ & $\begin{array}{l}30 \\
\text { STARCH }\end{array}$ \\
\hline MFI & $\begin{array}{l}\text { ASTM } \\
1238\end{array}$ & D & $\begin{array}{l}\text { g/10 } \\
\text { min }\end{array}$ & 8.838 & 7.672 & 6.935 & 5.786 \\
\hline VSP & $\begin{array}{l}\text { ASTM } \\
1525\end{array}$ & D & C & 101.24 & 102.67 & 104.32 & 105.48 \\
\hline
\end{tabular}

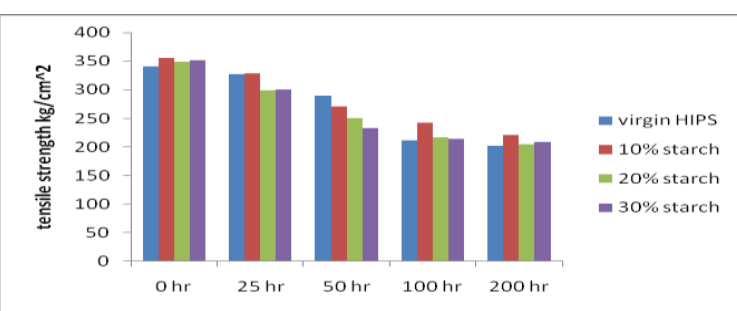

Fig 1 Tensile Strength before and after UV weathering of HIPS-Starch blends

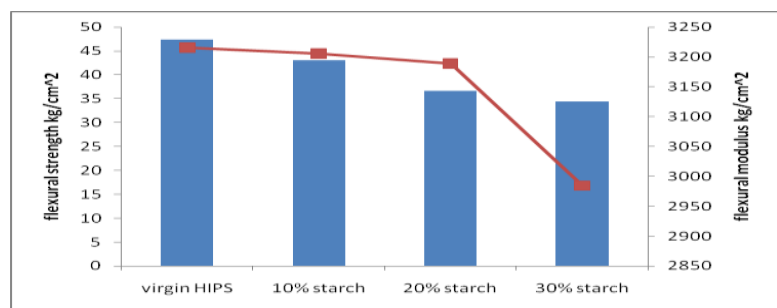

Figure 2. Flexural Strength and Modulus of HIPS-Starch blends 


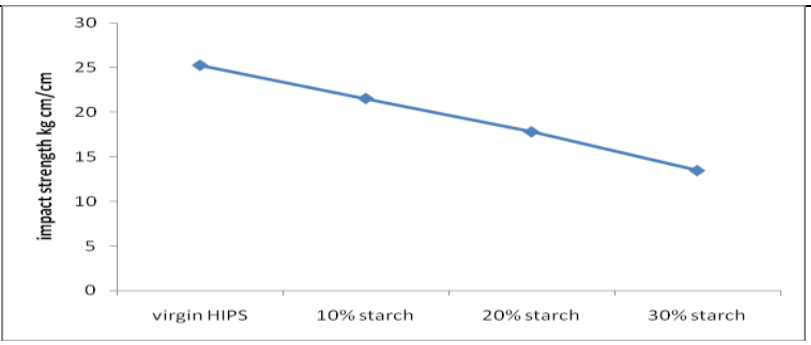

Figure 3 Impact strength of HIPS-Starch blends

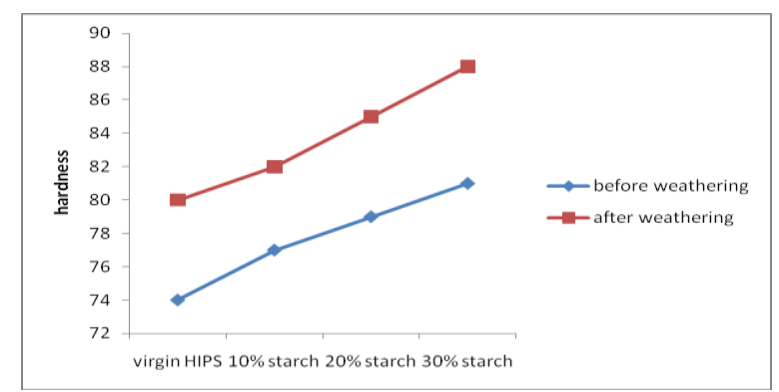

Figure 4 Hardness of HIPS-Starch blends

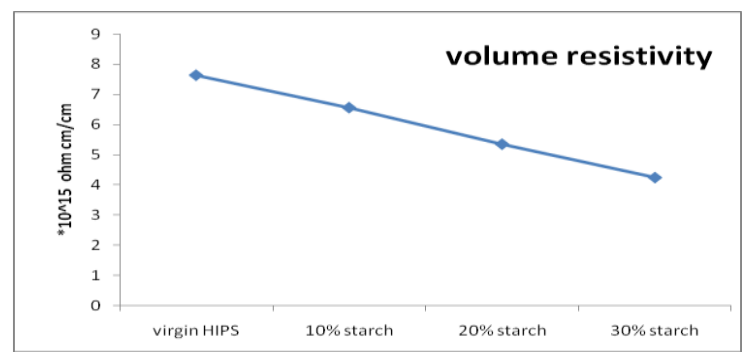

Figure 5 Volume Resistivity of HIPS-Starch blends

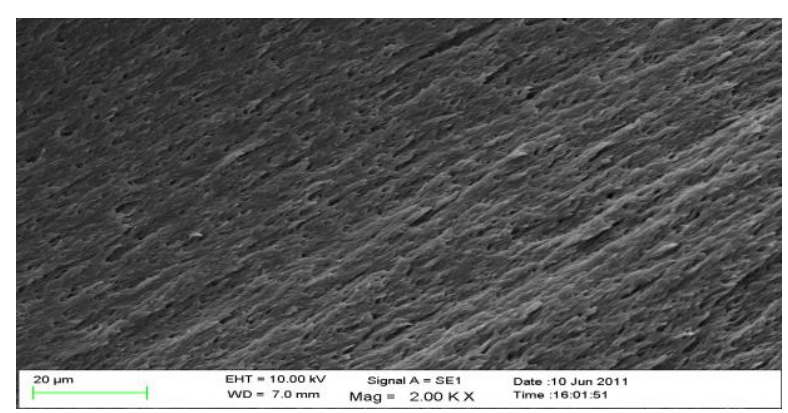

Figure 6 (a) Virgin HIPS before weathering

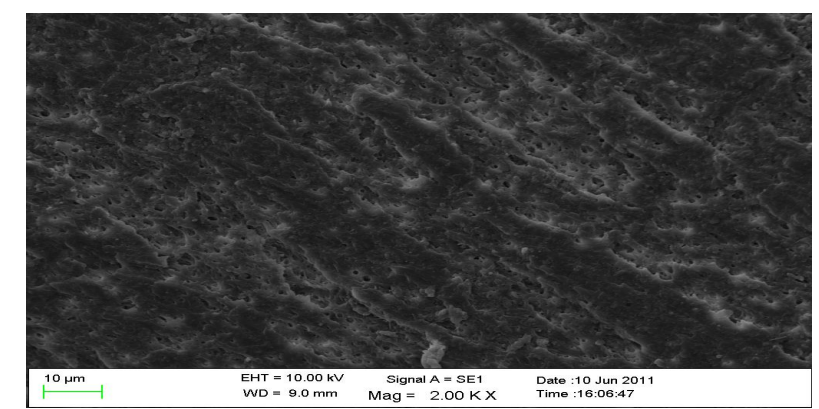

Figure 6 (b) Virgin HIPS after weathering

www.iosrjournals.org 


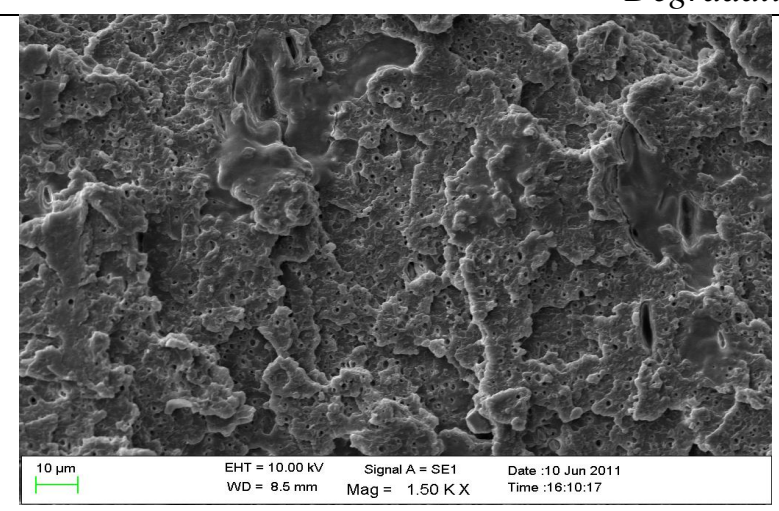

Figure 7 (a) HIPS with $10 \%$ starch before weathering

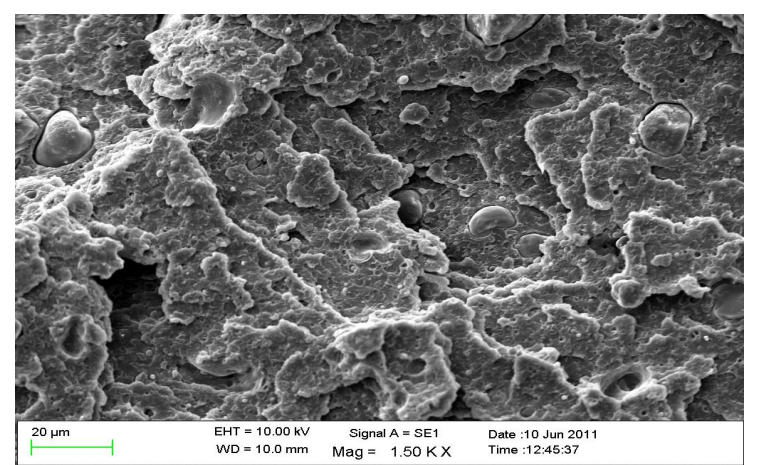

Figure 7 (b) HIPS with 10\% starch after 200 HRS UV Accellerated weathering

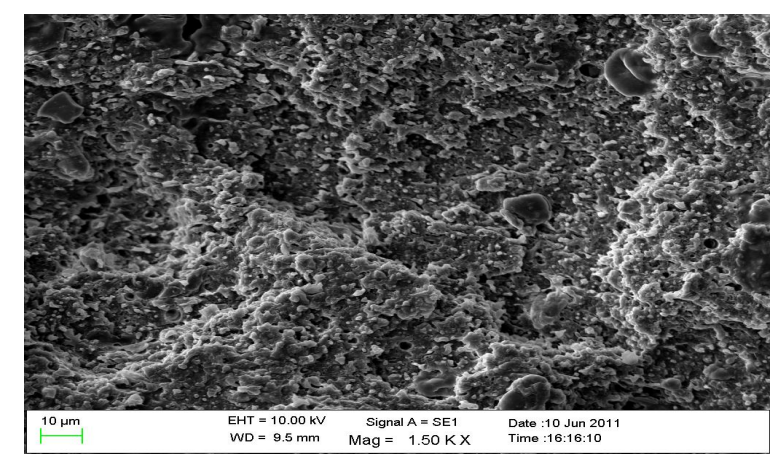

Figure 8 (a) HIPS with $20 \%$ starch before weathering

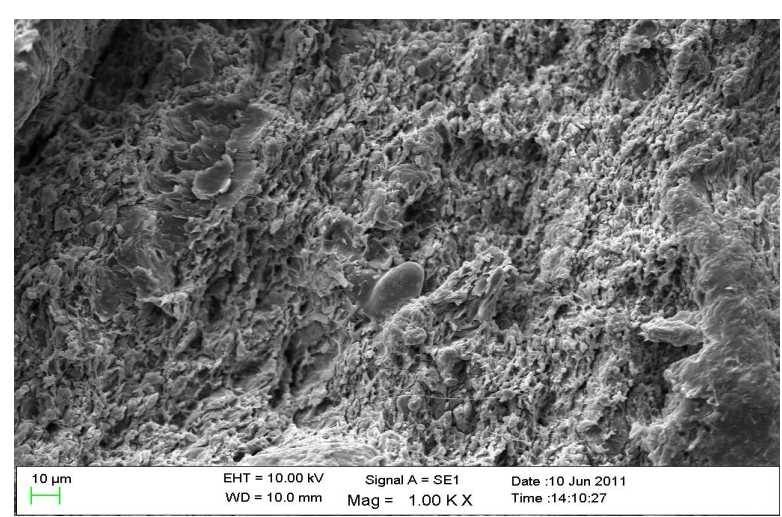

Figure 8 (b) HIPS with $20 \%$ starch after 200 HRS UV Accellerated weathering 


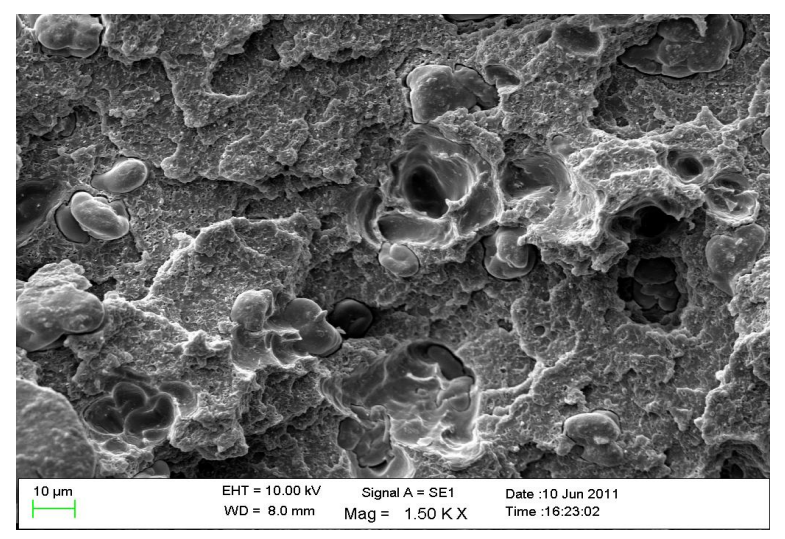

Figure 9 (a) HIPS with $30 \%$ starch before weathering.

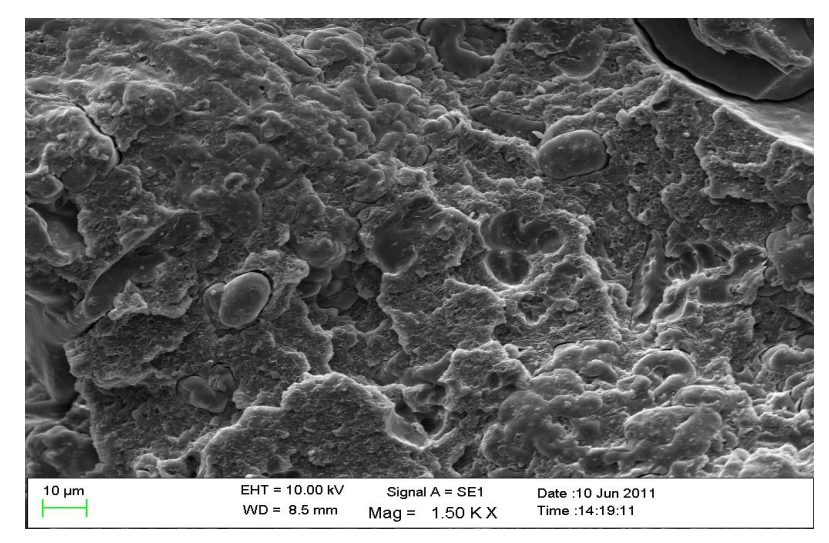

Figure 9 (b) HIPS with $30 \%$ starch after 200 HRS UV Accellerated weathering 